\title{
The Practicality and Effectiveness of Collaborative Creativity Learning (CCL) Model by Using PhET Simulation to Increase Students' Scientific Creativity
}

\section{Sri Astutik}

Dr, University of Jember, Indonesia, tika.fkip@unej. ac.id

\section{Binar Kurnia Prahani}

Dr, corresponding author, State Islamic University of Sunan Ampel, Indonesia, binarprahani@gmail.com

Using Collaborative Creativity Learning (CCL) model that is integrated with PhET simulation, this study aims to improve students' scientific creativity in natural science lesson. This research is an experimental study. The sample in this study is 144 junior high school students. The practicality and effectiveness of CCL model that is integrated with PhET simulation was measured by using practical learning observation sheet, scientific creativity test sheet, and student response questionnaire. The data was analysed using t-test, descriptively and qualitatively. The CCL model that is integrated with PhET simulation to improve students' scientific creativity has been proven to be: 1) Practical (applicable in learning and practical and reliable category) and 2) Effective includes: (a) a significant increase in students' scientific creativity at $\alpha=5 \%$, (b) the average n-gain of students' scientific creativity was medium, and (c) the student's response to each component of learning was very positive. The implication of this research is that CCL model that is integrated with PhET simulation can be used as a solution to improve students' creativity in natural science lesson.

Keywords: collaborative creativity learning, PhET simulation, scientific creativity, natural science lesson, learning

\section{INTRODUCTION}

The junior high school education has an important role in preparing students to innovate in the global era of Fourth Industrial Revolution (4IR). The junior secondary school must be able to provide learners who have the expertise to compete and excel. To succeed in the global era of Fourth Industrial Revolution (4IR), students need skills that support them such as creativity, critical thinking, problem solving, innovation, literacy, communication, responsibility and collaboration (Griffin \& Care, 2015; Jatmiko et al.,

Citation: Astutik, S., \& Prahani, B. K. (2018). The Practicality and Effectiveness of Collaborative Creativity Learning (CCL) Model by Using PhET Simulation to Increase Students' Scientific Creativity. International Journal of Instruction, 11(4), 409-424. https://doi.org/10.12973/iji.2018.11426a 
2016; Jatmiko et al., 2018; Pandiangan et al., 2017; Sunarti et al., 2018; Suyidno et al., 2016; Suyidno et al., 2018; Wicaksono et al., 2017). The development of students' scientific creativity is one of the main goals of education (Suyidno et al., 2018; Wicaksono et al., 2017). Scientific creativity is a high level-thinking skill to create original ideas and products that have scientific benefits (Ayas \& Sak 2014; Hu \& Adey 2010; Hu, et al., 2013; Kang et al., 2015; Raj \& Saxena, 2016; Siew et al., 2014; Susantini et al., 2016; Suyidno et al., 2017; Suyidno et al., 2018; Wicaksono et al., 2017). Previous researchers have also explained that scientific creativity as cognitive skill is reflected through unusual use, technical production, hypothesizing, science problem solving, creative experimental, and science production (Ayas \& Sak 2014; Hu \& Adey 2010; Hu, et al., 2013; Kang et al., 2015; Raj \& Saxena, 2016; Siew et al., 2014; Suyidno et al., 2017; Suyidno et al., 2018; Wicaksono et al., 2017). The indicators of scientific creativity in this study include unusual use, technical production, creative experimental, science problem solving, science production and hypothesizing based on the results of literature studies (Hu \& Adey 2010; Hu, et al., 2013; Suyidno et al., 2018; Wicaksono et al., 2017) and preliminary study by researchers (Astutik, 2015; Astutik et al., 2016), the six indicators are still low and need to be improved by junior high school students in the natural science lesson.

The facts of education in Indonesia show that students have not maximized their ability to think scientifically (OECD, 2014; 2016). This is reinforced by preliminary study about (1) The low skill of scientific creativity of junior high school students in natural science learning and (2) Limitations of teachers to develop models and learning tools of science that are specifically designed to enhance students' scientific creativity (Astutik et al., 2015). In order to improve students' scientific creativity in natural science learning, it needs an appropriate learning model, one of them is collaborative creativity learning (CCL) model as a solution to improve students' scientific creativity in natural science lesson (Astutik, 2015; Astutik et al., 2016).

The CCL model is a collaborative-based scientific creativity learning to enhance scientific creativity based on motivational theory, cognitive psychology theory, social constructivism learning theory, positive dependence and cognitive psychological theory (Astutik, 2015; Astutik et al., 2016). The CCL model has been proved to be feasible (valid, practical, and effective) to improve students' scientific creativity in natural science learning (Astutik, 2015; Astutik et al., 2016), but there are still short comings that need to be fixed to improve scientific creativity especially for junior high school students with low imagination. The solution proposed in this research is to integrate PhET simulation in CCL model implementation. The research results have proven that the integration of virtual simulation and PhET simulation in the learning process is effective to optimize student learning outcomes (Arabacioglu \& Unver, 2016; Prahani et al., 2015; Prahani et al., 2016; Sudiarman et al., 2015; Wicaksono et al., 2017). PhET simulation is a fun and interactive research based science and mathematics simulations that able to represent information in various representations (visual, verbal, and mathematical) (Finkelstein et al., 2005; Perkins et al., 2006; Prahani et al., 2016; Wieman et al., 2010;). This is reinforced by learning theory of dual coding; information that is presented visually or verbally is remembered better than information that is 
presented only in one way (Slavin, 2011). This is reinforced by research results (Ainsworth 1999; Ainsworth, 2008; Ciais et al., 2005; Maor, 2001) that the multirepresentation approach has three major advantages, as a complement, interpretation barrier, and can build a more comprehensive understanding. The CCL-that is integrated with PhET simulation has five syntaxes: (1) Problem identification, (2) Exploration of creativity ideas, (3) Collaborative creativity, (4) Elaboration of creativity ideas, and (5) Evaluate the process and results of scientific creativity.

The focus of this study is a follow-up study based on recommendations (20-21) to see the practicality and effectiveness of CCL model that is integrated with PhET simulation. This research was conducted to find an answer to the following questions: (i) How practicality of collaborative creativity learning model by using PhET simulation to improve the scientific creativity of junior high school students in natural science learning? (ii) How effectiveness of collaborative creativity learning model by using PhET simulation to improve the scientific creativity of junior high school students in natural science learning?

\section{METHOD}

\section{General Background}

This research was conducted in academic year 2017 in natural science subjects. The study was emphasized on the practicality and effectiveness analysis of CCL model that is integrated with $\mathrm{PhET}$ simulation model to improve students' scientific creativity. Practicality analysis of teaching model was done by calculating the mean score (observation scores) of learning implementation with CCL model that is integrated with PhET simulation in each phase. While the effectiveness analysis of CCL model that is integrated with PhET simulation was done by testing the difference of mean score between pre-test and post-test statistically at $\alpha=5 \%$, calculating the mean of n-gain, and calculating the mean percentage of student responses for each component. The questionnaire of student response to obtain the students' response of implementation of CCL model.

\section{Sample of Research}

The selection of samples is based on the Slovin formula, i.e. Sample $=$ (population $/(1+$ $\mathrm{e}^{2} \mathrm{x}$ population)) with error tolerance $\mathrm{e}=5 \%$ (Sevilla et al., 1984). The sample in this study is144 junior high school students in 2016 in Jember, Indonesia; and consists of four groups; group-1 (students of group VIIIB, state junior high school 3 Jember), group-2 (students of class VIIIB state junior high school 3 Jember), group-3 (students of class VIIIA state junior high school 2 Jember), and group-4 (students of class VIIIB state junior high school 2 Jember).

\section{Instrument and Procedures of Research}

This research is an experimental study by using one group pre-test and post-test design, namely: O1 X O2 (Fraenkel et al., 2012). Before groups of students learn about mechanics topics, students were given a pre-test of scientific creativity (O1) by using Scientific Creativity Test Sheet (SCTS). The indicators of scientific creativity in natural 
science subjects used in SCTS include unusual use, technical production, hypothesizing, science problem solving, creative experimental, and science production. Then the students were given a lesson on the topic of mechanics by using CCL model that is integrated with PhET simulation $(\mathrm{X})$. The CCL model that is integrated with PhET simulation has five phases include: (1) Identifying problem by using PhET simulation, (2) Exploring creativity ideas by using PhET simulation,(3) Collaborative creativity with PhET simulation, (4) Elaborating creativity ideas, (5) Evaluating the process and results of scientific creativity. Implementation of CCL model that is integrated with PhET simulation was supported learning tools consisted of Syllabus, Learning Lesson Plan, Student Instruction (student book), and Student Activity Sheet (worksheet). Syllabus, lesson plan, student book, and worksheet were valid and reliable, respectively in Table 1. After the learning process had been complete, all student groups were given a post-test (O2), final test with the same topic and problem as the pre-test. In the meantime, to obtain data about students' scientific creativity abilities, learning effectiveness, and student responses; the instruments that have also been valid and reliable were used.

Before the research is done, learning instruments and research instruments that have been compiled must meet the requirements of validity and reliability. The validity of learning instruments of CCL Model, and research instruments were assessed by three experts. The results of the validity assessment of the learning instruments and research instruments for CCL Model, respectively, are shown in Table 1.

Table 1

The result of learning instruments and research instruments validity of CCL model CCL model that is integrated with PhET simulation

\begin{tabular}{lll}
\hline \multirow{2}{*}{ Components } & \multicolumn{2}{c}{ The validity of CCL model instruments } \\
\cline { 2 - 3 } & \multicolumn{1}{c}{ Validity } & Reliability \\
\hline Syllabus & $3.80:$ Valid & $100 \%$ : Reliable \\
Lesson plan & $3.90:$ Valid & $100 \%$ : Reliable \\
Student book & $3.80:$ Valid & $100 \%$ : Reliable \\
Student Worksheet & $3.90:$ Valid & $90 \%:$ Reliable \\
Scientific Creativity Test Sheet & 3.71 : Valid & $90.00 \%$ : Reliable \\
Practical Learning Observation Sheet & $3.87:$ Valid & $94.82 \%$ : Reliable \\
Student Response Questionnaire & $3.71:$ Valid & $89.00 \%$ : Reliable \\
\hline
\end{tabular}

\section{Data Analysis}

The collected data were analysed to obtain practicality and effectiveness of learning with CCL model that is integrated with PhET simulation to improve students' scientific creativity. The analysis of practicality data of CCL model that is integrated with PhET simulation was done by using the calculation of the average score (observation score) of the each phase implementation of CCL model that is integrated with PhET simulation. There were 3 practitioners who observed the each phase implementation of CCL model that is integrated with PhET simulation. It was categorized as good if: the average percentage of the implementation score of each phase $\geq 2.50$ (this the mean score for the observers` scores); reliable, based on inter observer agreement; learning activity is 
categorized as reliably if the percentage agreement value for the mean percentage of the implementation score of each phase is $\geq 75 \%$ (Borich, 1994), the results respectively are shown in Table 2. Meanwhile, the effectiveness analysis of CCL model that is integrated with PhET simulation was done by analysing the mean of pre-test and post-test scores by using: (a) paired-sample t-test or Wilcoxon's test (Gibbons \& Chakraborti, 2011); (b) calculate the average of $n$-gain by the formula: $n$-gain $=$ (post-test score / pre-test score) / maximum score - post-test score), by category: (1) high if $n$-gain $\geq 0.70 ;$ (2) moderate if $0.70>n$-gain $\geq 0.30$; and (3) low if n-gain < 0.30 (Hake, 1998); and (c) calculate student response to CCL model that is integrated with PhET simulation; students' responses are said good if the average percentage of student response scores for each component is $\geq 75 \%$. In order to see the responses of junior high school students toward CCL model that is integrated with PhET simulation, student responses data was analysed by using elaborated of quantitative and qualitative descriptive (Prahani et al., 2015 ) With the criteria of: (1) Response $\geq 75 \%$ (very positive); (2) $50 \% \leq$ Response < $75 \%$ (positive); (3) $25 \% \leq$ Response $<50 \%$ (less positive); and (4) Response $<25 \%$ (not positive).

\section{FINDINGS}

\section{Practicality of CCL Model by Using PhET Simulation}

Practicality scores for each phase of CCL model that is integrated with PhET simulation model for all groups are presented in Table 2.

Table 2

Practicality of CCL model that is integrated with PhET simulation at all groups

\begin{tabular}{lllllllllllll}
\hline Syntax & \multicolumn{1}{c}{ Group-1 } & \multicolumn{4}{c}{ Group-2 } & \multicolumn{4}{c}{ Group-3 } & \multicolumn{3}{c}{ Group-4 } \\
\cline { 2 - 12 } & S & C & r & S & C & r & S & C & r & S & C & r \\
\hline Phase I & 3.57 & VP & R & 3.54 & VP & R & 3.52 & VP & R & 3.52 & VP & R \\
Phase II & 3.49 & VP & R & 3.47 & VP & R & 3.48 & VP & R & 3.31 & VP & R \\
Phase III & 3.50 & VP & R & 3.41 & VP & R & 3.38 & VP & R & 3.36 & VP & R \\
Phase IV & 3.26 & VP & R & 3.22 & VP & R & 3.26 & VP & R & 3.26 & VP & R \\
Phase V & 3.62 & VP & R & 3.59 & VP & R & 3.62 & VP & R & 3.59 & VP & R \\
\hline
\end{tabular}

Note: S (Score); C (Criteria); VP (Very Practical); r (Reliability); R (Reliable); Phase I (Problem identification); Phase II (Exploration of creativity ideas); Phase III (Collaborative creativity); Phase IV (Elaboration of creativity ideas); and Phase V (Evaluation of scientific creativity process and result)

Table 2 presents the results of practical analysis in terms of the implementation of each phase of CCL model that is integrated with PhET simulation. The analysis of practicality data of CCL model that is integrated with PhET simulation was done by using the calculation of the average score (observation score) of the each phase implementation of CCL model that is integrated with PhET simulation. There were 3 practitioners who observed the each phase implementation of CCL model that is integrated with PhET simulation. The practicality of CCL model that is integrated with PhET simulation was observed in each meeting for all groups. The results of the analysis show that each phase CCL model that is integrated with PhET simulation can be implemented by teachers in each group with very practical and reliable categories. Based on these results, it is clear that the role of teachers is very supportive in natural science learning by using scientific 
collaboration, so it gains good scientific creativity. Briefly, students' activity by using CCL model that is integrated with PhET simulation on natural science learning is presented in Table 3.

Table 3

Students' activity by using CCL model that is integrated with PhET simulation at natural science learning

Students' activities

Phase 1, Problem Identification: Establishing a CC working group, through the help of PhET Simulation students identify problems based on some activities, for example by observing a physiological phenomenon that can be easily encountered in everyday life, observing demonstrations, doing simple experiments, and conveying learning objectives.

Phase 2, Exploration of creativity ideas: The group thinks of alternative solutions by exploring the ideas as much as possible from each member. The ideas collected are discussed to determine the best fit idea as a solution or the solution can also be determined from the combination of members' ideas. Then the students design their experiments to be done with the help of PhET Simulation.

Phase 3, Collaborative creativity: The group works in collaborative experiments with the help of PhET Simulation based on group creativity and collects data. Each student contributes a new idea to the experimental results. Then the best idea or combined idea is analysed for further conclusion.

Phase 4, Elaboration of creativity ideas: The elaboration of the creativity idea is accomplished by completing grains of scientific creativity whose completion is associated with learning materials. The items of scientific creativity that are solved are: 1) Unusual Use (UU), 2) Technical Production (TP), 3) Hypothesizing (H), 4) Science Problem Solving (SPS), 5) Creative Experimental (CE) and 6) Science Product (SP).

Phase 5, Evaluation of scientific creativity process and result: Evaluation of the whole process by providing feedback on students' work. Evaluations are conducted on aspects of scientific collaboration and students' scientific creativity indicators and the results will be confirmed by criteria for the assessment of scientific creativity and scientific collaboration. Students are also asked their impression about learning with the help of PhET Simulation.

\section{Effectiveness of CCL Model by Using PhET Simulation}

The effectiveness of CCL Model that is integrated with PhET Simulation is presented in Table 4, Table 5, Table 6, and Table 7. Table 4 describes the mean scores of pre-test, post-test and n-gain of scientific creativity in all groups. In all groups the average pretest score was $0.10-1.07$ (low category). This is because the students still have many difficulties and unfamiliar to implement scientific creativity in solving the natural science problem. Students feel unfamiliar and claim scientific creativity is new.

Table 4

Mean pre-test, post-test, and n-gain scores of scientific creativity at all groups

\begin{tabular}{lllllll}
\hline \multirow{2}{*}{ Group } & \multicolumn{7}{l}{ Scientific creativity at all groups } \\
\cline { 2 - 6 } & Pre-test & Post-test & N-gain & \\
\hline Group-1 & 0.17 & Low & 0.76 & High & 0.72 & High \\
Group-2 & 0.17 & Low & 0.77 & High & 0.74 & High \\
Group-3 & 0.14 & Low & 0.75 & High & 0.71 & High \\
Group-4 & 0.10 & Low & 0.73 & High & 0.71 & High \\
\hline
\end{tabular}


In contrast, the post-test scores after the implementation of CCL model that is integrated with PhET simulation in all groups were $0.76,0.77,0.75$, and 0.73 and were in the high category, it is presented in Table 3 . Table 3 shows that n-gain of scientific creativity of junior high students in all groups were $0.72,0.74,0.71$, and 0.71 in high category. The increase in scientific creativity of junior high school students in natural science subjects is because the role of teachers is very important and sensitive to produce learning in collaborative creativity, because the demands in this phase is that students are able to create creativity in collaborative groups so that teachers also have to be sensitive to students' problem in the group. When students get into trouble in carrying out the experiment, the teacher must guide and provide solutions to the problems faced by students. The mean pre-test, post-test, and n-gain scores of scientific creativity at all groups is presented in Table 5.

Table 5

The mean pre-test, post-test, and n-gain scores of scientific creativity at all groups

\begin{tabular}{|c|c|c|c|c|c|c|c|c|c|c|c|c|c|}
\hline \multirow{2}{*}{\multicolumn{2}{|c|}{ Scores }} & \multicolumn{12}{|c|}{ Scientific Creativity Indicators } \\
\hline & & $\overline{\mathrm{UU}}$ & & TP & & $\mathrm{H}$ & & SPS & & $\overline{\mathrm{CE}}$ & & SP & \\
\hline \multirow[t]{3}{*}{ G1 } & $\overline{\mathrm{O} 1}$ & 1.31 & $\mathrm{~L}$ & 1.57 & $\mathrm{~L}$ & 1.63 & $\mathrm{~L}$ & 0.82 & $\mathrm{~L}$ & 1.41 & $\mathrm{~L}$ & 0.64 & $\mathrm{~L}$ \\
\hline & $\mathrm{O} 2$ & 3.25 & $\mathrm{H}$ & 2.76 & $\mathrm{H}$ & 3.05 & $\mathrm{H}$ & 2.40 & $\mathrm{M}$ & 3.20 & $\mathrm{H}$ & 2.96 & $\mathrm{H}$ \\
\hline & $\langle g\rangle$ & 0.72 & $\mathrm{H}$ & 0.49 & M & 0.60 & M & 0.50 & M & 0.69 & M & 0.69 & $\mathrm{M}$ \\
\hline \multirow[t]{3}{*}{$\mathrm{G} 2$} & $\mathrm{O} 1$ & 1.56 & $\mathrm{~L}$ & 1.50 & $\mathrm{~L}$ & 1.78 & $\mathrm{~L}$ & 1.50 & $\mathrm{~L}$ & 1.70 & $\mathrm{~L}$ & 1.60 & $\mathrm{~L}$ \\
\hline & $\mathrm{O} 2$ & 3.33 & $\mathrm{H}$ & 2.78 & $\mathrm{H}$ & 3.20 & $\mathrm{H}$ & 2.78 & $\mathrm{H}$ & 3.28 & $\mathrm{H}$ & 3.27 & $\mathrm{H}$ \\
\hline & $\langle\mathrm{g}\rangle$ & 0.72 & $\mathrm{H}$ & 0.51 & M & 0.64 & $\mathrm{M}$ & 0.51 & $\mathrm{M}$ & 0.69 & $\mathrm{M}$ & 0.70 & $\mathrm{M}$ \\
\hline \multirow[t]{3}{*}{ G3 } & $\mathrm{O} 1$ & 1.56 & $\mathrm{~L}$ & 1.71 & $\mathrm{~L}$ & 1.68 & $\mathrm{~L}$ & 1.42 & $\mathrm{~L}$ & 1.59 & $\mathrm{~L}$ & 1.66 & $\mathrm{~L}$ \\
\hline & $\mathrm{O} 2$ & 3.33 & $\mathrm{H}$ & 2.99 & $\mathrm{H}$ & 3.16 & $\mathrm{H}$ & 2.63 & $\mathrm{M}$ & 3.03 & $\mathrm{H}$ & 3.09 & $\mathrm{H}$ \\
\hline & $\langle\mathrm{g}\rangle$ & 0.72 & $\mathrm{H}$ & 0.56 & M & 0.64 & M & 0.47 & M & 0.60 & M & 0.61 & $\mathrm{M}$ \\
\hline \multirow[t]{3}{*}{ G4 } & $\mathrm{O} 1$ & 1.31 & $\mathrm{~L}$ & 1.60 & $\mathrm{~L}$ & 1.78 & $\mathrm{~L}$ & 1.01 & $\mathrm{~L}$ & 1.60 & $\mathrm{~L}$ & 1.64 & $\mathrm{~L}$ \\
\hline & $\mathrm{O} 2$ & 3.25 & $\mathrm{H}$ & 2.86 & $\mathrm{H}$ & 3.20 & $\mathrm{H}$ & 2.44 & M & 2.99 & $\mathrm{H}$ & 3.07 & $\mathrm{H}$ \\
\hline & $\langle\mathrm{g}\rangle$ & 0.72 & $\mathrm{H}$ & 0.53 & M & 0.64 & M & 0.48 & $\mathrm{M}$ & 0.58 & $\mathrm{M}$ & 0.61 & M \\
\hline
\end{tabular}

Note: G1 (Group-1); G2 (Group-2); G3 (Group-3); G4 (Group-4); O1 (Pre-test); O2 (Post-test); 〈g〉 (N-gain); UU (Unusual Use); TP (Technical Production); H (Hypothesizing); SPS (Science Problem Solving); CE (Creative Experimental); SP (Science Production); L (Low); M (Moderate); H (High)

Table 5 shows that all indicators of scientific creativity in the pre-test are in low category, whereas after the implementation of science learning with the CCL model that is integrated PhET simulation informs that all the indicators of scientific creativity has increased. The general n-gain of scientific creativity indicator was above 0.47 (medium category). The positive result is because the implementation of natural science teaching with CCL model that is integrated PhET simulation has been designed to improve scientific creativity indicator include unusual use, technical production, hypothesizing, science problem solving, creative experimental, and science production through phases of CCL model that is integrated PhET simulation. The syntax of CCL model that is integrated PhET simulation include of (1) Identification of problem by using PhET simulation; (2) Exploration of creativity ideas by using PhET simulation; (3) Collaborative creativity by using PhET simulation; (4) Elaboration of creativity ideas; (5) The scientific process and results evaluation. 
The results of the normality and homogeneity test of variance showed that the pre-test, post-test, and n-gain scores of scientific creativity were homogeneous and normally distributed for the whole group. The impact of the CCL model that is integrated with PhET simulation implementation in improving the scientific creativity of junior high school students in natural science subjects for all groups by using Paired t-test is presented in Table 6.

Table 6

The Results of scientific creativity Paired t-test at all groups

\begin{tabular}{lllllll}
\hline \multirow{2}{*}{ Group } & \multirow{2}{*}{$\mathrm{N}$} & \multicolumn{2}{l}{ Paired t-test, $\alpha=5 \%$} & $\mathrm{~d}$ & $\mathrm{p}$ \\
\cline { 3 - 7 } & & Mean & Std. error mean & $\mathrm{t}$ & $\mathrm{d}$ \\
\hline 1 & 36 & 1.67 & .07 & -24.44 & 35 & $<.00$ \\
2 & 36 & 1.67 & .07 & -23.49 & 35 & $<.00$ \\
3 & 36 & 1.41 & .08 & -17.23 & 35 & $<.00$ \\
4 & 36 & 1.23 & .07 & -16.38 & 35 & $<.00$ \\
\hline
\end{tabular}

Table 6 shows that the average scientific creativity for all groups is 1.67, 1.67, 1.41, 1.23 and has degrees of freedom $(\mathrm{df})=35 ; \mathrm{t}$ score gives $\mathrm{t}$ value $=-24.44,-23.49,-17.23$, and -16.38 . The Paired $\mathrm{t}$-test ( $\mathrm{p}$ ) test score shows $<.00$, because $\mathrm{p}<5 \%$, makes it significant. Since the result of the calculations has a negative value, it is clear that there is an increase in scientific creativity after the application of learning with CCL model that is integrated with PhET simulation for all groups. Inferential statistic of different test reinforced the belief that CCL model that is integrated with PhET simulation gives an impact to increase the scientific creativity of junior high school students in natural science subjects. The improvement of scientific creativity is supported by the response data that is presented in Table 7.

Table 7

Results of student response questionnaires at all groups

\begin{tabular}{|c|c|c|c|c|c|c|c|c|c|c|c|c|}
\hline Student Response & Group-1 & & & Group-2 & & & Group-3 & & & Group-4 & & \\
\hline Components & $\%$ (Yes) & C & 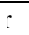 & $\%$ (Yes) & C & $\therefore$ & $\%$ (Yes) & I & : & $\%$ (Yes) & I & 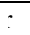 \\
\hline $\begin{array}{l}\text { Feel attracted to } \\
\text { learning materials and } \\
\text { how teachers teach }\end{array}$ & $76.20 \%$ & VP & $\mathrm{R}$ & $74.30 \%$ & VP & R & $74.10 \%$ & VP & $\mathrm{R}$ & $74.10 \%$ & VP & $\mathrm{R}$ \\
\hline $\begin{array}{l}\text { Feel new to learning } \\
\text { materials and how } \\
\text { teachers teach }\end{array}$ & $37.40 \%$ & VP & $R$ & $71.40 \%$ & VP & $R$ & $70.60 \%$ & VP & $R$ & $70.90 \%$ & VP & $R$ \\
\hline $\begin{array}{l}\text { Feel easy on learning } \\
\text { materials and how } \\
\text { teachers teach }\end{array}$ & $71.80 \%$ & VP & $\mathrm{R}$ & $74.30 \%$ & VP & $\mathrm{R}$ & $72.40 \%$ & VP & $\mathrm{R}$ & $72.00 \%$ & VP & $\mathrm{R}$ \\
\hline $\begin{array}{l}\text { Feel new to the } \\
\text { component of } \\
\text { scientific creativity }\end{array}$ & $95.70 \%$ & VP & $\mathrm{R}$ & $96.20 \%$ & VP & $\mathrm{R}$ & $73.10 \%$ & VP & $\mathrm{R}$ & $71.40 \%$ & VP & $\mathrm{R}$ \\
\hline $\begin{array}{l}\text { Feel new to the } \\
\text { scientific } \\
\text { collaboration } \\
\text { component }\end{array}$ & $96.50 \%$ & VP & $\mathrm{R}$ & $\ni 2.00 \%$ & VP & $\mathrm{R}$ & $\ni 1.80 \%$ & VP & $\mathrm{R}$ & $71.40 \%$ & VP & $\mathrm{R}$ \\
\hline $\begin{array}{l}\text { Feel capable to } \\
\text { perform scientific } \\
\text { creativity skills }\end{array}$ & $92.60 \%$ & VP & $\mathrm{R}$ & $71.90 \%$ & $P$ & $\mathrm{R}$ & $37.70 \%$ & VP & $\mathrm{R}$ & $36.70 \%$ & VP & $\mathrm{R}$ \\
\hline
\end{tabular}




\begin{tabular}{|c|c|c|c|c|c|c|c|c|c|c|c|c|}
\hline Student Response & Group-1 & & & Group-2 & & & Group-3 & & & Group-4 & & \\
\hline Components & $\%$ (Yes) & E & $\therefore$ & $\%$ (Yes) & E & $\therefore$ & $\%$ (Yes) & E & $\therefore$ & $\%$ (Yes) & I & 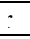 \\
\hline $\begin{array}{l}\text { Feel capable to do } \\
\text { scientific } \\
\text { collaboration }\end{array}$ & $73.50 \%$ & VP & $\mathrm{R}$ & $72.00 \%$ & VP & $\mathrm{R}$ & $70.90 \%$ & VP & $\mathrm{R}$ & $72.00 \%$ & VP & $\mathrm{R}$ \\
\hline $\begin{array}{l}\text { Feel interested in } \\
\text { following CCL } \\
\text { model that is } \\
\text { integrated with } \\
\text { PhET simulation }\end{array}$ & $94.30 \%$ & VP & $\mathrm{R}$ & $71.40 \%$ & VP & $\mathrm{R}$ & $100 \%$ & VP & $\mathrm{R}$ & $77.10 \%$ & VP & $\mathrm{R}$ \\
\hline $\begin{array}{l}\text { Feel easy in } \\
\text { exploring the idea of } \\
\text { creativity }\end{array}$ & $71.40 \%$ & $P$ & $\bar{R}$ & $35.70 \%$ & $P$ & $\bar{R}$ & $35.30 \%$ & $P$ & $\bar{R}$ & $38.60 \%$ & $P$ & $\mathrm{R}$ \\
\hline $\begin{array}{l}\text { Feel easy to do } \\
\text { collaborative } \\
\text { creativity }\end{array}$ & $32.90 \%$ & VP & $\mathrm{R}$ & $32.90 \%$ & VP & $\mathrm{R}$ & $35.30 \%$ & VP & $\mathrm{R}$ & $35.70 \%$ & VP & $\mathrm{R}$ \\
\hline $\begin{array}{l}\text { Feel easy to } \\
\text { elaborate creativity } \\
\text { ideas }\end{array}$ & $30.00 \%$ & VP & $\mathrm{R}$ & $35.70 \%$ & VP & $\mathrm{R}$ & $70.60 \%$ & $P$ & R & $30.00 \%$ & VP & $\mathrm{R}$ \\
\hline $\begin{array}{l}\text { Feel easy on } \\
\text { scientific test of } \\
\text { creativity }\end{array}$ & $77.10 \%$ & $P$ & $\bar{R}$ & $71.4 \%$ & $P$ & $\bar{R}$ & $73.50 \%$ & $P$ & $R$ & $35.70 \%$ & $P$ & $\mathrm{R}$ \\
\hline Average & $91.00 \%$ & VP & $\mathrm{R}$ & $30.00 \%$ & VP & $\mathrm{R}$ & $71.00 \%$ & $\mathrm{VP}$ & $\mathrm{R}$ & $70.00 \%$ & VP & $\mathrm{R}$ \\
\hline
\end{tabular}

Table 7 represents the results of student responses that in general the percentage of student responses to the learning by using CCL that is integrated with PhET simulation and $90.50 \%$ of the device responded very positively. The improvement of scientific creativity of junior high school students in natural science subjects is also because teachers are able to perform their duties as a good facilitator, mentor and mediator during the implementation of CCL that is integrated with PhET simulation model.

\section{DISCUSSION}

\section{Practicality of CCL Model by Using PhET Simulation}

The CCL model that is integrated with PhET simulation has five phases include: (1) Identifying problem by using PhET simulation, (2) Exploring creativity ideas by using PhET simulation,(3) Collaborative creativity with PhET simulation, (4) Elaborating creativity ideas, (5) Evaluating the process and results of scientific creativity. Practicality scores for each phase of CCL model that is integrated with PhET simulation model for all groups are presented in Table 3. The learning outcomes that have been obtained provide evidence that CCL model that is integrated with PhET simulation meets the model criteria from the practicality side (Nieveen et al., 2007). Thus, it can be said that the scientific creativity skill is good for natural science learning, as well as scientific collaboration can be used natural science learning. The established relationship between scientific work and scientific creativity is that scientific work can make a positive contribution to the improvement of scientific learning achievement (Aktamis \& Ergin, 2008). This is supported by previous research that the CCL model was developed to teach scientific creativity and scientific collaboration has been valid and can be used to teach science (Astutik, 2018). Therefore, CCL model that is 
integrated with PhET simulation model are proved very practical to improve the scientific creativity of high school students in natural science learning.

\section{Effectiveness of CCL Model by Using PhET Simulation}

In all groups the average pre-test score was in low category (Table 4). This is because the students still have many difficulties and unfamiliar to implement scientific creativity in solving the natural science problem. Students feel unfamiliar and claim scientific creativity is new. The findings are in accordance with the results of preliminary studies conducted by researchers that the scientific creativity of junior high students is still relatively low. This finding is also reinforced by the research results of Astutik (2015), Astutik (2018), Jatmiko et al. (2016), Jatmiko et al. (2018), Suyidno et al. (2018) that students still have difficulties in scientific creativity, collaborative, and problem-solving skills. The underlying causes of scientific creativity are in accordance with the theory of functional atonement Solso et al. (2008) that students tend to see things based on the usual uses and are difficult in accepting new perspectives that are actually needed in problem solving. It is supported by Mueller et al. (2012) that a person is born creatively, but the barriers of creativity often interface the ability to recognize creative ideas.

The findings of an increase in scientific creativity (Finding in Table 4) is in line with Vygotsky social constructivist theory, scaffolding; students should be given complex, difficult, and realistic tasks and then given sufficient help to solve these tasks (Slavin, 2011). Assistance can be given in the form of gradual assistance (scaffolding) so that students actually learn to gain knowledge and can be released when the students no longer need help. The science process skill in CCL model that is integrated with PhET provides an important role in improving the scientific creativity of junior high school students. The process of science has a role in promoting scientific creativity and is closely related to scientific creativity (Aktamis \& Ergin, 2008; Jones et al., 2008). This is because scientific creativity has been developed to meet the validity (content and constructs) to enhance scientific creativity and scientific collaboration of junior high school students (Astutik, 2015; Astutik, 2018). This is supported by the results of the study (Astutik, 2015; Astutik, 2018; Erika et al., 2018; Husamah et al, 2018; Limatahu et al., 2018; Madeali \& Prahani, 2018; Prahani et al., 2016; Prahani et al., 2018; Purwaningsih et al., 2018; Suprapto et al., 2018; Suyidno et al., 2017) that the learning and teaching model that is feasible to meet the validity (content and construct), practicality, and effectiveness will be able to improve and achieve the learning objectives.

In order to gain a good mastery of scientific creativity skills (Finding in Table 5), the learning steps is done by using science process skills and to overcome the weakness of the science process skills, in the early stages of learning, gradual assistance is given (scaffolding) to students. For example, gradual assistance to students is given until students obtain knowledge and they are gradually released when teacher believes that they can do it by themselves. The guidance given to students includes the understanding of problem formulation, formulation of hypotheses, variable identification and determination the operational variables definition. At this stage, to overcome student difficulties teachers are expected to find suitable strategies or methods related to 
problem formulation, hypotheses formulation, variables identification and formulation of operational variables definition to build their trust and identity in learning (Grossen, 2008). The third phase of CCL model is collaborative creativity by using PhET simulation (collaborative creativity), which is an activity to carry out collaborative experiments by performing instruction that is written on the worksheet with the help of PhET simulation. With the help of PhET simulation students work individually and collaboratively in the acquisition of data which and then the results are written on the worksheet.

Significant improvement on scientific creativity of junior high school students in science subjects after the CCL model that is integrated with PhET simulation (Finding Table 6) cannot be separated from the availability of valid learning. Further, it is said that the learning environment which supports the learning process includes the planning of all learning aspects such as the ability of teachers to teach, appropriate media, and clear learning objectives, adequate learning resources and allocating the time properly. The results are reinforced with theoretical and empiric support that CCL model that is integrated with PhET simulation is a collaborative-based scientific learning creativity by using PhET simulation that is designed to improve scientific creativity based on motivational theory, cognitive psychology theory, social constructivism learning theory, positive dependence and cognitive psychology theory (Arends, 2012; Astutik et al., 2016; Moreno, 2010; Slavin, 2011). Therefore, CCL model that is integrated with PhET simulation is proved to be effective to improve students' scientific creativity in natural science lesson.

The results of student responses which indicate that the students (a very positive response) stated that they easily understand the way the teacher teaches. These findings (Findings in Table 7) are in accordance with the social constructivist theory of Vygotsky (Arends, 2012; Moreno, 2010; Slavin, 2011). The results of questionnaire showed that students feel their scientific creativity was increased. In addition, students also feel an increase in scientific collaboration. The result of this questionnaire proves that the nurture effect of the CCL model by using PhET simulation is able to improve to the scientific collaboration of junior high school students in natural science learning. Overall, it can be said that CCL that is integrated with PhET simulation fulfils the practical and effective criteria to improve the scientific creativity of junior high school students in natural science lesson. According to the results of this study implementation of CCL that is integrated with PhET simulation has been proven to be practical and effective in improving the scientific creativity of junior high school students.

\section{CONCLUSION}

The CCL model that is integrated with PhET simulation is collaborative-based scientific creativity learning by using the help of PhET simulation by design to enhance scientific creativity based on motivational theory, cognitive psychology theory, social constructivism learning theory, positive dependence and cognitive psychology theory. The natural science learning that use CCL model that is integrated with PhET simulation to improve the scientific creativity of junior high school students has been proven: (1) practical (applicable in learning with high practical and reliable category) and (2) 
effective, as demonstrated by: (a) a significant increase in students' scientific creativity on $\alpha=5 \%$, (b) average n-gain of students' creativity was in medium category, and (c) student's response to each component of learning is categorized as very positive. The questionnaire results showed that students feel their scientific creativity was increased. In addition, students also feel an increase in scientific collaboration. The result of this questionnaire proves that the nurture effect of the CCL model with the help of PhET simulation is able to improve the scientific collaboration of junior high school students in natural science learning. The implication of this research is that CCL model that is integrated with PhET simulation can be used to improve the creativity of junior high school students in natural science learning in Indonesia. Further research can be dome on CCL model that is integrated with PhET simulation for elementary, secondary, and college level to see the model's practicality and effectiveness at these levels.

\section{ACKNOWLEDGEMENTS}

The author's gratitude goes to the Ministry of Research, Technology and Higher Education for funding the Research. Likewise, the author's gratitude goes to the University of Jember, State Islamic University of Sunan Ampel, State Junior High School 2 Jember, and State Junior High School 3 Jember that have provided collaborative research opportunities.

\section{REFERENCES}

Ainsworth, S. (1999). The functions of multiple representations. Computers \& Education, 33(2), 131-152.

Ainsworth, S. (2008). The educational value of multiple-representations when learning complex scientific concepts. Visualization: Theory and practice in science Education. New York: Springer.

Aktamis, H. and Ergin, O. (2008). The effect scientific process skills education on student's scientific creativity, science attitudes, and academic achievement. Asia-Pacific Forum on Science learning and Teaching, 9(1), 1-21.

Arabacioglu, S. and Unver, A.O. (2016). Supporting inquiry based laboratory practices with mobile learning to enhance students' process skills in science education. Journal of Baltic Science Education, 15(2), 216-230.

Arends, R. I. (2012). Learning to teach. New York: Mc. Graw-Hill.

Astutik, S. (2018). Pengembangan Model Collaborative Creativity untuk Meningaktkan Kreativitas Ilmiah dan Afektif Collaborative Siswa SMP (Development of Collaborative Creativity Model to Enhance Scientific Creativity and Affective Collaborative Junior High School Students). Surabaya: Pascasarjana Unesa.

Astutik, S., Nur, M., and Susantini, E. (2015). Development of the hypothetical model to teach the skills of scientific creativity students in learning science. The National Conference on Research, Reform of education in the entering Asean Community (AEC), Jember: 959-968. 
Astutik, S., Nur, M., and Susantini, E. (2016). Validity of collaborative creativity (CC) models. The 3 International Conference on Research, Implementation and Education of Mathematics and Science, Yogyakarta: 73-78.

Ayas, M.B. and Sak, U. (2014). Objective measure of scientific creativity: Psychometric validity of the creative scientific ability test. Thinking Skills and Creativity, 13, 195-205.

Borich, G. (1994). Observation skill for effective teaching. New York: Mac Millan Publishing Company.

Ciais, P., Reichstein, M., Viovy, N., Granier, A., Ogée, J., Allard, V., and Carrara, A. (2005). Europe-wide reduction in primary productivity caused by the heat and drought in 2003. Nature, 437(7058), 529-533.

Erika, F., Prahani, B.K., Supardi, Z.A.I., \& Tukiran. (2018). The development of metacognition-based learning media for the industrial electronics field in a vocational high school. World Trans. on Engng. and Technol. Educ., 16(2), 179-185.

Finkelstein, N.D., Adams, W.K., Keller, C.J., Kohl, P.B., Perkins, K.K., Podolefsky, N.S., Reid, S., and LeMaster, R. (2005). When learning about the real world is better done virtually: A Study of substituting computer simulation for laboratory equipment. Physical Review Special Topics-Physics Education Research, 1, 010103.

Fraenkel, J., Wallen, N., and Hyun, H. (2012). How to design and evaluate research in education (8th Ed.). New York: McGraw-Hill.

Gibbons, J.D. and Chakraborti, S. (2011). Nonparametric statistical inference. Tuscaloosa: CRC Press.

Griffin, P. and Care, E. (2015). Assessment and teaching of 21 st century skills: Methods and approach. New York: Springer.

Grossen, M. (2008). Methods for studying collaborative creativity: An original and adventurous blend. Thinking Skills and Creativity, 3, 246-249.

Hake, R.R. (1998). Interactive-engagement versus traditional methods: A six-thousandstudent survey of mechanics test data for introductory physics courses. American Journal of Physics, 66(1), 64-74.

Hu, W. and Adey, P. (2010). A scientific creativity test for secondary school students. International Journal of Science Education, 24(4), 389-403.

Hu, W., Wu, B., Jia, X., Yi, X., Duan, C., and Meyer, W. (2013). Increasing student's scientific creativity: The "learn to think" intervention program. The Journal of Creative Behavior, 47(1), 3-21.

Husamah, Fatmawati, D., and Setyawan, D. (2018). OIDDE learning model: Improving higher order thinking skills of biology teacher candidates. International Journal of Instruction, 11(2), 249-264. 
Jatmiko, B., Prahani, B.K., Munasir, Supardi, Z.A.I., Wicaksono, I., Erlina, N., Pandiangan, P., Althaf, R., and Zainuddin. (2018). The comparison of OR-IPA teaching model and problem based learning model effectiveness to improve critical thinking skills of pre-service physics teachers. Journal of Baltic Science Education, 17(2), 1-22.

Jatmiko, B., Widodo, W., Martini, Budiyanto, M., Wicaksono, I., and Pandiangan, P. (2016). Effectiveness of the INQF-based learning on a general physics for improving student's learning outcomes. Journal of Baltic Science Education, 15(4), 441-451.

Jones, A., Miells D., Littleton K., and Vass, E. (2008). The discourse of collaborative creativity writing: Peer collaboration as a context for mutual inspiration. Thinking Skill and Creativity Journal, 3, 92-202.

Kang, K.A., Kim, S., Kim, S.J., Oh, J., and Lee, M. (2015). Comparison of knowledge, confidence in skills performance (CSP) and satisfaction in problem-based learning (PBL) and simulation with $P B L$ educational modalities in caring for children with bronchiolitis. Nurse Education Today, 35(2), 315-321.

Limatahu I., Suyatno, Wasis, and Prahani, B.K. (2018). The effectiveness of CCDSR learning model to improve skills of creating lesson plan and worksheet science process skill (SPS) for pre-service physics teacher. Journal of Physics: Conference Series, 997(32), 1-7.

Madeali, H. and Prahani, B.K. (2018). Development of multimedia learning based inquiry on vibration and wave material. Journal of Physics: Conference Series, 997(29), $1-7$.

Maor, D. (2001). Development and formative evaluation of a multimedia program using interpretive research methodology. Journal of Computers in Mathematics and Science Teaching, 20(1), 75-98.

Moreno, R. (2010). Educational psychology. New Mexico. John Wiley \& Sons, Inc.

Mueller, J.S., Melwani, S., and Goncalo, J.A. (2012). The bias against creativity: Why people desire but reject creative ideas. Psychology Science, 23(1), 13-17.

Nieveen, N., McKenney, S., \& van. Akker. (2007). Educational design research. New York: Routledge.

OECD. (2014). PISA 2012 Results. Washington: OECD Publishing.

OECD. (2016). PISA 2015 Result in Focus. Washington: OECD Publishing.

Pandiangan, P., Sanjaya, M., Gusti, I., and Jatmiko, B. (2017). The validity and effectiveness of physics independent learning model to improve physics problem solving and self-directed learning skills of students in open and distance education systems. Journal of Baltic Science Education, 16(5), 651-665.

Perkins, K., Adams, W., Dubson, M., Finkelstein, N., Reid, S., and Wieman, C. (2006). PhET: Interactive simulations for teaching and learning physics. The Physics Teacher, 44, 18-20. 
Prahani, B. K., Winata, S. W., and Yuanita, L. (2015). Pengembangan perangkat pembelajaran fisika model inkuiri terbimbing untuk melatihkan keterampilan penyelesaian masalah berbasis multi representasi siswa SMA [The development of physics learning model of inquiry model is guided to solve problem-solving skills based on multi representation of high school students]. Jurnal Penelitian Pendidikan Sains, 4 (2), 503-517.

Prahani, B.K., Limatahu, I., Winata, S.W., Yuanita, L., \& Nur, M. (2016). Effectiveness of physics learning material through guided inquiry model to improve student's problem solving skills based on multiple representation. International Journal of Education and Research. 4(12), 231-244.

Prahani, B.K., Nur, M., Yuanita, L., and Limatahu, I. (2016). Validitas model pembelajaran group science learning: Pembelajaran inovatif di Indonesia [Validity of learning model of group science learning: Innovative learning in Indonesia]. Vidhya Karya, 31(1), 72-80.

Prahani, B.K., Suprapto, N., Suliyanah, Lestari, N.A., Jauhariyah, M.N.R, Admoko, S., and Wahyuni, S. (2018). The effectiveness of collaborative problem based physics learning (CPBPL) model to improve student's self-confidence on physics learning. Journal of Physics: Conference Series, 997(08), 1-6.

Purwaningsih, E., Suyatno, Wasis, and Prahani, B.K. (2018). The effectiveness of comcorels model to improve skills of creating physics lesson plan (CPLP) for preservice physics teacher. Journal of Physics: Conference Series, 997(22), 1-7.

Raj, H. and Saxena, D.R. (2016). Scientific creativity: A review of researches. European Academic Research, 4, 1122-1138.

Sevilla, C.G., Ochave, J.A., Punsalan, T.G., Regala, B.P., and Uriarte, G.G. (1984). An introduction to research methods. Quezon City: Rex Printing Company.

Siew, N. M., Chong, C.L., and Chin, K.O. (2014). Developing a scientific creativity test for fifth graders. Problems of Education in the 21st Century, 62(1), 109-123.

Slavin, R.E. (2011). Educational psychology, theory and practice. Boston: Pearson Education.

Solso, R.L., MacLin, O.H., and MacLin, M.K. (2008). Cognitive psychology, 8th edition. Boston: Pearson Education.

Sudiarman, Soegimin, W.W., and Susantini, E. (2015) Pengembangan perangkat pembelajaran fisika berbasis inkuiri terbimbing untuk melatihkan keterampilan proses sains dan meningkatkan hasil belajar pada topik suhu dan perubahannya [Development of physics-based inquiry-based learning tools to trace the skills of the science process and improve learning outcomes on the topic of temperature and its changes]. Jurnal Penelitian Pendidikan Sains, 4(2), 636-647. 
Sunarti T., Wasis, Madlazim, Suyidno, and Prahani, B.K. (2018). The effectiveness of CPI model to improve positive attitude toward science (PATS) for pre-service physics teacher. Journal of Physics: Conference Series, 997(13), 1-7.

Suprapto, N., Suliyanah, Prahani, B.K., Jauhariyah, M.N.R., and Admoko, S. (2018). Exploring physics concepts among novice teacher through CMAP tools. Journal Physics: Conference Series, 997(11), 1-7.

Susantini, E., Isnawati, and Lisdiana, L. (2016). Effectiveness of genetics student worksheet to improve creative thinking skills of teacher candidate students. Journal of Science Education, 2(17), 74-79.

Suyidno, Nur, M., Yuanita, L., and Prahani, B.K. (2017). Validity of creative responsibility based learning: An innovative physics learning to prepare the generation of creative and responsibility. Journal of Research \& Method in Education, 7(1), 56-61.

Suyidno, Nur, M., Yuanita, L., Prahani, B.K., and Jatmiko, B. (2018). Effectiveness of creative responsibility based teaching (CRBT) model on basic physics learning to increase student's scientific creativity and responsibility. Journal of Baltic Science Education, 17(1), 136-151.

Suyidno, Nur, M., Yuanita, L., Sunarti, T., and Prahani, B. K. (2016). Student's responsibilites department PMIPA of Lambung Mangkurat University in learning physics. Jurnal Vidya Karya FKIP Universitas Lambung Mangkurat, 2, 46-59.

Wicaksono, I., Wasis, and Madlazim. (2017). The effectiveness of virtual science teaching model (VS-TM) to improve student's scientific creativity and concept mastery on senior high school physics subject. Journal of Baltic Science Education, 16(4), 549561 .

Wieman, C.E., Adams, W.K., Loeblein, P., and Perkins, K.K., (2010). Teaching physics using PhET simulations. The Physics Teacher, 48, 225-227. 